\title{
Do Changes Occur in Hemodynamic Parameters, Hemogram, Renal Function and Serum Electrolytes during Percutaneous Nephrolithotomy? Its Correlation with Irrigation Fluid and Intravenous Fluid
}

\author{
Chetan R. Kulkarni, Subodh R. Shivde, Jaydeep A. Date, Rohan S. Valsangkar \\ Department of Urology and Transplant Services, Deenanath Mangeshkar Hospital and Research Centre, Pune, Maharashtra, India \\ Email: shivdes@gmail.com, chetanrk1988@gmail.com
}

How to cite this paper: Kulkarni, C.R., Shivde, S.R., Date, J.A. and Valsangkar, R.S. (2022) Do Changes Occur in Hemodynamic Parameters, Hemogram, Renal Function and Serum Electrolytes during Percutaneous Nephrolithotomy? Its Correlation with Irrigation Fluid and Intravenous Fluid. Open Journal of Urology, 12, 57-68.

https://doi.org/10.4236/oju.2022.121006

Received: October 6, 2021

Accepted: January 14, 2022

Published: January 17, 2022

Copyright (๑) 2022 by author(s) and Scientific Research Publishing Inc. This work is licensed under the Creative Commons Attribution International License (CC BY 4.0).

http://creativecommons.org/licenses/by/4.0/

\begin{abstract}
Introduction: Percutaneous nephrolithotomy (PCNL) is a standard minimally invasive urological procedure for the treatment of large renal calculi. It is also associated with complications arising from absorption of irrigation fluid and intravenous fluid injection. We evaluated the changes occurring in vital and blood parameters during PCNL using $0.9 \%$ normal saline (NS) as an irrigation fluid. Materials and Methods: We prospectively studied 71 patients who underwent PCNL in our hospital between 2016 and 2018. NS $(0.9 \%)$ was used as irrigation fluid in all patients. Changes in hemodynamics, hemogram, renal function tests and serum electrolytes were noted and assessed for significance using paired $t$-test. These changes were correlated with ASA grade, BMI, total operating time, total irrigation fluid used and total intravenous fluid used using Pearson's correlation test. Results: A significant fall in serum creatinine was present $(1.30 \pm 0.96$ vs. $1.24 \pm 0.93)$ along with a rise in eGFR ( $85.39 \pm 24.10$ vs. $90.18 \pm 22.58)$. A significant rise in serum potassium $(4.34 \pm 0.45$ vs. $4.5 \pm 0.56)$ and chloride levels (104.79 \pm 3.51 vs. $106.69 \pm 3.14)$ post-operatively was noted. A significant rise in pulse rate $(80.84 \pm 10.13$ vs. $87.76 \pm 13.12)$ and systolic blood pressure $(127.67 \pm 15.90$ vs. $136.88 \pm 19.56)$ post-operatively was noted. There was no significant change noted in hemoglobin, PCV, platelets and serum sodium levels. Total operating time and irrigation fluid volume showed a positive correlation with changes in eGFR, serum chloride, post-operative pulse rate and blood pressure values. Intravenous fluids volume correlated positively with changes in serum potassium, chloride, post-operative pulse rate and blood pressure values. Conclusion: High amount of irrigation fluid absorption can cause early
\end{abstract}


post-operative changes in patients' hemodynamics and blood indices. Overzealous hydration during PCNL with potassium containing fluids can also lead to hyperkalemia and hyperchloremic acidosis. Thus, early post-operative monitoring of serum electrolytes should be done in all patients after PCNL to prevent complications arising from dyselectrolytemia.

\section{Keywords}

Percutaneous Nephrolithotomy, Hemodynamic Parameters, Hemogram, Renal Function and Serum Electrolytes

\section{Introduction}

Percutaneous nephrolithotomy (PCNL) is a minimally invasive urological procedure to remove large renal calculi $(>2 \mathrm{~cm})$ in renal pelvis and calyces. It is also a standard option in stones $<2 \mathrm{~cm}$ where extracorporeal shock wave lithotripsy (ESWL) and retrograde intrarenal surgery (RIRS) are contra-indicated or have failed to clear the stone. It has successfully replaced open stone surgery due to its numerous advantages, namely, less morbidity, less hospital stay and a smaller scar [1].

However, complications unique to PCNL are also encountered. Use of irrigation fluid leads to hemodynamic and electrolyte complications due to intravascular absorption of irrigation fluid either due to extravasation or intravasation [2]. Studies showing the effects of intravenous fluid on hemodynamic, renal function test, hemogram and electrolyte changes are sparse and their results are variable. Some studies show no change in hemodynamics [3] [4] [5] while some studies show a rise in post-operative pulse rate and blood pressure [6] [7]. Similarly, some studies show no change in sodium levels [3] [8] while others show a fall in sodium levels [6] [7]. Even fewer studies show the effect of irrigation and intravenous fluid on serum potassium and chloride.

We have attempted to find hemodynamic, hemogram, renal function test and electrolyte changes occurring post-operatively after percutaneous nephrolithotomy (PCNL). We have attempted to correlate these changes with BMI, ASA grade, total volume of irrigation fluid, total operating time and total intravenous fluid injection.

\section{Material and Methods}

Data was obtained from 71 patients who underwent primary PCNL in a tertiary care centre hospital in Pune, India from 2016-2018. Ethical committee clearance was obtained from the institution and informed consent was taken from all patients.

1) Patients included:

a) All patients above 18 years of age;

b) All patients who preferred PCNL as primary mode of treatment of renal 
calculi;

c) All patients with American Society of Anesthesiologist (ASA) grade l, 1.

2) Patients excluded:

a) All patients with ASA grade lll, lV;

b) All patients with uncorrected coagulopathy;

c) All pregnant females;

d) All patients taking medications which alter electrolytes;

e) All patients receiving an intraoperative blood transfusion.

Hemoglobin, packed cell volume, creatinine, eGFR, serum sodium, serum potassium and serum chloride were measured within 3 days from date of surgery and within 30 minutes post-operatively in recovery room. Pre-operative pulse rate and blood pressure were measured in pre-operative room 1 hour before surgery, intra-operatively pulse rate blood pressure was measured every $5 \mathrm{mi}$ nutes and post-operative pulse and blood pressure were measured 15 minutes after extubation.

1 dose of IV Ciprofloxacin was used in all patients pre-operatively with negative urine culture. Those who had pre-operative positive culture were treated with an appropriate sensitive antibiotic before surgery and the same was given intra-operatively. Nephrotoxic antibiotics were avoided. All procedures were done under general anesthesia. Fentanyl or midazolam was given before intubation. Propofol and atracurium were used during intubation and sevofluorane was the anesthetic choice for maintenance. After deploying $6 \mathrm{Fr}$. ureteric catheter, patients were turned prone. Puncture was done according to position of stone and it was done under fluoroscopy guidance. Serial dilatation was done till 24Fr. using Alken metal dilators and Amplatz sheath was used in all patients. Stone was fragmented using lithoclast and $0.9 \%$ normal saline was used for irrigation. All fragments were extracted, full visual and fluoroscopic clearance was achieved. 20Fr nephrostomy tube was used in all patients. Ringer's lactate or plasmalyte was given intravenously as per requirement. Total operating time and total volume of irrigation fluid used were measured.

All methods to reduce absorption of irrigation fluid were implemented, namely use of Amplatz sheath, irrigation without pressure, height of irrigation lower than $100 \mathrm{~cm}$., operating time limited to 120 minutes, puncture under fluoroscopic control and serial dilatation to avoid pelvic or ureteric perforation.

Paired t-test was used to assess significance of changes in hemogram, electrolytes, renal function tests and hemodynamic indices and Pearson's correlation test was used to assess correlation between BMI, ASA, total operating time, total irrigation fluid volume and total IV fluids volume with changes in hemogram, electrolytes, renal function tests and hemodynamic indices. $p$ values of $<$ 0.05 was taken as significant.

\section{Results}

A total of 71 patients were selected in our study. 53 (74.64\%) were males and 18 
(25.36\%) were females. Mean age was $52.56 \pm 13.16$ years. 33 patients $(46.47 \%)$ had stone in right kidney and 38 patients (53.53\%) had stone in left kidney. 48 patients $(67.60 \%)$ had one or two comorbidities which were managed and controlled pre-operatively. Mean BMI was $25.24 \pm 4.52 .23$ patients (32.39\%) were ASA grade 1 and 48 patients (67.60\%) were ASA grade 2. Mean stone size was $27 \pm 11.61 \mathrm{~mm}$. Mean operating time was $104.92 \pm 34.47$ minutes and mean total volume of irrigation fluid was $21.76 \pm 11.22$ liters (Table 1 ).

Mean fall in hemoglobin (13.08 $\pm 2.32 \mathrm{gm} / \mathrm{dl}$ vs. $12.99 \pm 2.13 \mathrm{gm} / \mathrm{dl})$, packed cell volume $(39.78 \% \pm 6.48 \%$ vs. $39.62 \% \pm 5.80 \%)$ and platelets $(282,766 \pm$ $82,441.63$ cells $/ \mathrm{cmm}$ vs. $266,550 \pm 102,981.56$ cells $/ \mathrm{cmm}$ ) was noted which was not statistically significant. A significant rise in total leukocyte count was noted $(8605.39 \pm 2764.24$ cells $/ \mathrm{cmm}$ vs. $10,919.18 \pm 4093.79 \mathrm{cells} / \mathrm{cmm})$ (Table 2$)$.

A significant drop in serum creatinine was present $(1.30 \pm 0.96 \mathrm{mg} / \mathrm{dl}$ vs. $1.24 \pm$ $0.93 \mathrm{mg} / \mathrm{dl})$. A significant rise in eGFR was present $(85.39 \pm 0.96 \mathrm{ml} / \mathrm{min} \mathrm{vs}$. $90.18 \pm 22.58 \mathrm{ml} / \mathrm{min}$ ). There was no statistically significant change in serum sodium concentration $(137.76 \pm 3.22$ vs. $138.10 \pm 2.54)$. There was statistically significant increase in post-operative serum potassium level $(4.34 \pm 0.45$ vs. $4.5 \pm$ $0.56)$ and chloride levels (104.79 \pm 3.51 vs. $106.69 \pm 3.14)$ post-operatively (Table 3). 3 patients had potassium levels above normal range but none of the patients developed clinical manifestations secondary to hyperkalemia. All 3 patients were promptly treated for hyperkalemia. 27/71 (38.02\%) patients developed post-operative asymptomatic hyperchloremic acidosis.

Intra-operatively there was no significant change in heart rate $(80.84 \pm 10.13$ beats/min vs. $77.98 \pm 10.04$ beats/min). Statistically significant intra-operative fall in systolic blood pressure $(127.67 \pm 15.90 \mathrm{mmHg}$ vs. $116.76 \pm 8.84 \mathrm{mmHg})$

Table 1. Patient demographics.

\begin{tabular}{llc}
\hline Patients & & 71 \\
Age(years) & Male & $52.56 \pm 13.16$ \\
Sex & Female & $52(74.64 \%)$ \\
& Right & $19(25.36 \%)$ \\
Laterality & Left & $33(46.47 \%)$ \\
Stone size(mm) & & $38(53.53 \%)$ \\
Operating time(minutes) & & $27 \pm 11.61$ \\
Irrigation fluid(litres) & & $104.92 \pm 34.47$ \\
Irrigation fluid height(cm) & & $21.76 \pm 11.22$ \\
ASA & Grade l & 80 \\
BMI & Grade ll & $23(32.39 \%)$ \\
Comorbidities & & $48(67.60 \%)$ \\
\end{tabular}


Table 2. Peri-operativechanges in hemogram.

\begin{tabular}{cccc}
\hline & Preop & Postop & $p$ value \\
\hline $\begin{array}{c}\text { Haemoglobin } \\
\text { (gm/dl) }\end{array}$ & $13.08 \pm 2.32$ & $12.99 \pm 2.13$ & 0.3714 \\
PCV (\%) & $39.78 \pm 6.48$ & $39.62 \pm 5.80$ & 0.9416 \\
TLC (cells/cmm) & $8605.39 \pm 2764.24$ & $10,919 \pm 4093.79$ & 0.0001 \\
Platelets (cells/cmm) & $272,785.71 \pm 70,926.44$ & $266,550 \pm 102,981.56$ & 0.1485 \\
\hline
\end{tabular}

Table 3. Peri-operative changes in renal function tests and serum electrolytes.

\begin{tabular}{cccc}
\hline & Preop & Postop & $p$ value \\
\hline Creatinine $(\mathrm{mg} / \mathrm{dl})$ & $1.30 \pm 0.96$ & $1.24 \pm 0.93$ & 0.0204 \\
eGFR $(\mathrm{ml} / \mathrm{min})$ & $85.39 \pm 24.10$ & $90.18 \pm 22.58$ & 0.0046 \\
Sodium $(\mathrm{mEq} / \mathrm{L})$ & $137.76 \pm 3.22$ & $138.10 \pm 2.54$ & 0.324 \\
Potassium $(\mathrm{mEq} / \mathrm{L})$ & $4.34 \pm 0.45$ & $4.5 \pm 0.56$ & 0.0336 \\
Chloride $(\mathrm{mEq} / \mathrm{L})$ & $104.79 \pm 3.51$ & $106.69 \pm 3.14$ & 0.0001 \\
\hline
\end{tabular}

and diastolic pressure $(79.64 \pm 9.90 \mathrm{mmHg}$ vs. $68.64 \pm 6.98 \mathrm{mmHg})$ was present. Statistically significant rise in pulse rate $(80.84 \pm 10.13$ beats/min vs. $87.76 \pm$ 13.12 beats/min) and systolic blood pressure $(127.67 \pm 15.90 \mathrm{mmHg}$ vs. $136.88 \pm$ $19.56 \mathrm{mmHg}$ ) was seen post-operatively. There was no significant difference in diastolic blood pressure $(79.64 \pm 9.90 \mathrm{mmHg}$ vs. $80.91 \pm 10.75 \mathrm{mmHg}$ ) (Table 4).

Total operating time, irrigation fluid, intravenous fluid, ASA and BMI did not show correlation with drop in hemoglobin, PCV and platelet values. Rise in TLC had a positive correlation with BMI and IV fluids (Table 5).

Total operating time and irrigation fluid volume showed positive correlation with changes in serum creatinine and chloride levels. Total intravenous fluid volume showed positive correlation with changes in serum sodium, potassium and chloride levels. ASA grade showed positive correlation with changes in eGFR, serum sodium and potassium (Table 6).

Total operating time had a positive correlation with change in intra-operative and post-operative pulse rate. Total irrigation fluid had a positive correlation with intra-operative pulse rate and changes in post-operative pulse rate, systolic and diastolic blood pressure. Total intravenous fluid volume had a positive correlation with changes in post-operative pulse rate and systolic and diastolic blood pressure. BMI correlated positively with intra-operative fall in systolic and diastolic blood pressure and post-operative rise in heart rate. ASA correlated positively with rise in post-operative heart rate and systolic blood pressure (Table 7). 
Table 4. Peri-operative changes in hemodynamics.

\begin{tabular}{cccccc}
\hline & Preop & Intraop & $p$ value & Postop & $p$ value \\
\hline Pulse (beats/min) & $80.84 \pm 10.13$ & $77.98 \pm 10.04$ & 0.0517 & $87.76 \pm 13.12$ & 0.0004 \\
$\begin{array}{c}\text { Systolic BP } \\
(\mathrm{mmHg})\end{array}$ & $127.67 \pm 15.90$ & $116.76 \pm 8.84$ & 0.0001 & $136.88 \pm 19.56$ & 0.0021 \\
$\begin{array}{c}\text { Diastolic BP } \\
(\mathrm{mmHg})\end{array}$ & $79.64 \pm 9.90$ & $68.634 \pm 6.98$ & 0.0001 & $80.91 \pm 10.75$ & 0.4616 \\
\hline
\end{tabular}

Table 5. Correlation of changes occuring in hemogram with operating time, amount of irrigation fluid, body mass index (BMI), ASA scale and amount of intravenous fluid.

\begin{tabular}{ccccc}
\hline & Hb & PCV & TLC & Platelets \\
\hline $\begin{array}{c}\text { Operating time } \\
\text { (minutes) }\end{array}$ & $\mathrm{R}=-0.0765$ & $\mathrm{R}=-0.1238$ & $\mathrm{R}=-0.0154$ & $\mathrm{R}=-0.2309$ \\
& $\mathrm{P}=0.544177$ & $\mathrm{P}=0.349132$ & $\mathrm{P}=0.916795$ & $\mathrm{P}=0.088141$ \\
$\mathbf{0 . 9 \%}$ NS (litres) & $\mathrm{R}=-0.1373$ & $\mathrm{R}=-0.1763$ & $\mathrm{R}=-0.0462$ & $\mathrm{R}=-0.2624$ \\
& $\mathrm{P}=0.298169$ & $\mathrm{P}=0.17858$ & $\mathrm{P}=0.724819$ & $\mathrm{P}=0.051101$ \\
BMI & $\mathrm{R}=-0.0389$ & $\mathrm{R}=-0.0408$ & $\mathrm{R}=0.1995$ & $\mathrm{R}=-0.0928$ \\
& $\mathrm{P}=0.761947$ & $\mathrm{P}=0.761553$ & $\mathrm{P}=0.123207$ & $\mathrm{P}=0.500076$ \\
& $\mathrm{R}=-0.0258$ & $\mathrm{R}=-0.0562$ & $\mathrm{R}=-0.0651$ & $\mathrm{R}=-0.03$ \\
& $\mathrm{P}=0.842066$ & $\mathrm{P}=0.670849$ & $\mathrm{P}=0.618702$ & $\mathrm{P}=0.826272$ \\
& $\mathrm{R}=-0.0036$ & $\mathrm{R}=-0.0646$ & $\mathrm{R}=0.0451$ & $\mathrm{R}=-0.1799$ \\
& $\mathrm{P}=0.980927$ & $\mathrm{P}=0.609682$ & $\mathrm{P}=0.729996$ & $\mathrm{P}=0.186838$ \\
\hline
\end{tabular}

Table 6. Correlation of changes occurring in renal function tests and serum electrolytes with operating time, amount of irrigation fluid, body mass index (BMI), ASA scale and amount of intravenous fluid.

\begin{tabular}{|c|c|c|c|c|c|}
\hline & Crea & eGFR & $\mathrm{Na}^{+}$ & $\mathrm{K}^{+}$ & $\mathrm{Cl}^{-}$ \\
\hline $\begin{array}{c}\text { Operating } \\
\text { time } \\
\text { (minutes) }\end{array}$ & $\begin{array}{l}\mathrm{R}=-0.1219 \\
\mathrm{P}=0.352937\end{array}$ & $\begin{array}{c}\mathrm{R}=0.0073 \\
\mathrm{P}=0.959453\end{array}$ & $\begin{array}{c}\mathrm{R}=0.0291 \\
\mathrm{P}=0.808349\end{array}$ & $\begin{array}{l}\mathrm{R}=-0.0477 \\
\mathrm{P}=0.678809\end{array}$ & $\begin{array}{c}\mathrm{R}=0.0115 \\
\mathrm{P}=0.924169\end{array}$ \\
\hline $\begin{array}{c}0.9 \% \text { NS } \\
\text { (litres) }\end{array}$ & $\begin{array}{l}\mathrm{R}=-0.0727 \\
\mathrm{P}=0.581345\end{array}$ & $\begin{array}{c}\mathrm{R}=0.1446 \\
\mathrm{P}=0.311355\end{array}$ & $\begin{array}{l}\mathrm{R}=-0.0842 \\
\mathrm{P}=0.486137\end{array}$ & $\begin{array}{l}\mathrm{R}=-0.0237 \\
\mathrm{P}=0.849006\end{array}$ & $\begin{array}{c}\mathrm{R}=0.0093 \\
\mathrm{P}=0.938644\end{array}$ \\
\hline BMI & $\begin{array}{l}\mathrm{R}=-0.0296 \\
\mathrm{P}=0.824424\end{array}$ & $\begin{array}{l}\mathrm{R}=-0.1715 \\
\mathrm{P}=0.233006\end{array}$ & $\begin{array}{l}\mathrm{R}=-0.0855 \\
\mathrm{P}=0.480943\end{array}$ & $\begin{array}{l}\mathrm{R}=-0.1247 \\
\mathrm{P}=0.302879\end{array}$ & $\begin{array}{l}\mathrm{R}=-0.2136 \\
\mathrm{P}=0.074515\end{array}$ \\
\hline AS & $\begin{array}{l}\mathrm{R}=-0.0936 \\
\mathrm{P}=0.475924\end{array}$ & $\begin{array}{c}\mathrm{R}=0.2199 \\
\mathrm{P}=0.121018\end{array}$ & $\begin{array}{c}\mathrm{R}=0.1354 \\
\mathrm{P}=0.260232\end{array}$ & $\begin{array}{c}\mathrm{R}=0.0422 \\
\mathrm{P}=0.726768\end{array}$ & $\begin{array}{l}\mathrm{R}=-0.0193 \\
\mathrm{P}=0.875033\end{array}$ \\
\hline IV fluids (ml) & $\begin{array}{l}\mathrm{R}=-0.0759 \\
\mathrm{P}=0.565656\end{array}$ & $\begin{array}{l}\mathrm{R}=-0.0381 \\
\mathrm{P}=0.834465\end{array}$ & $\begin{array}{c}\mathrm{R}=0.1439 \\
\mathrm{P}=0.231212\end{array}$ & $\begin{array}{c}\mathrm{R}=0.0424 \\
\mathrm{P}=0.728013\end{array}$ & $\begin{array}{c}\mathrm{R}=0.0488 \\
\mathrm{P}=0.686111\end{array}$ \\
\hline
\end{tabular}


Table 7. Correlation of changes occurring in hemodynamics with operating time, amount of irrigation fluid, body mass index (BMI), ASA scale and amount of intravenous fluid.

\begin{tabular}{ccccccc}
\hline & Intraop P & Intraop SBP & Intraop DBP & Postop P & Postop SBP & Postop DBP \\
\hline $\begin{array}{c}\text { Operating time } \\
\text { (minutes) }\end{array}$ & $\mathrm{R}=0.1306$ & $\mathrm{R}=-0.022$ & $\mathrm{R}=-0.0864$ & $\mathrm{R}=0.0073$ & $\mathrm{R}=-0.0053$ & $\mathrm{R}=-0.091$ \\
& $\mathrm{P}=0.277665$ & $\mathrm{P}=0.85549$ & $\mathrm{P}=0.475778$ & $\mathrm{P}=0.951821$ & $\mathrm{P}=0.980191$ & $\mathrm{P}=0.450407$ \\
0.9\% NS (litres) & $\mathrm{R}=0.1631$ & $\mathrm{R}=-0.0315$ & $\mathrm{R}=-0.167$ & $\mathrm{R}=0.1973$ & $\mathrm{R}=0.1361$ & $\mathrm{R}=0.1123$ \\
& $\mathrm{P}=0.17413$ & $\mathrm{P}=0.79746$ & $\mathrm{P}=0.182578$ & $\mathrm{P}=0.099101$ & $\mathrm{P}=0.257753$ & $\mathrm{P}=0.351122$ \\
& $\mathrm{R}=-0.0837$ & $\mathrm{R}=0.1107$ & $\mathrm{R}=0.1542$ & $\mathrm{R}=0.0783$ & $\mathrm{R}=-0.022$ & $\mathrm{R}=-0.04$ \\
BMI & $\mathrm{P}=0.491361$ & $\mathrm{P}=0.358071$ & $\mathrm{P}=0.199161$ & $\mathrm{P}=0.516303$ & $\mathrm{P}=0.855499$ & $\mathrm{P}=0.740496$ \\
& $\mathrm{R}=-0.1475$ & $\mathrm{R}=-0.0035$ & $\mathrm{R}=0$ & $\mathrm{R}=0.0117$ & $\mathrm{R}=0.0298$ & $\mathrm{R}=-0.0102$ \\
& $\mathrm{P}=0.22121$ & $\mathrm{P}=0.980191$ & $\mathrm{P}=0.922854$ & $\mathrm{P}=0.805143$ & $\mathrm{P}=0.934036$ \\
& $\mathrm{R}=0.11$ & $\mathrm{R}=-0.0518$ & $\mathrm{R}=-0.1058$ & $\mathrm{R}=0.105$ & $\mathrm{R}=0.2065$ & $\mathrm{R}=0.0996$ \\
\hline IV fluids (ml) & $\mathrm{P}=0.351122$ & $\mathrm{P}=0.672747$ & $\mathrm{P}=0.383506$ & $\mathrm{P}=0.383506$ & $\mathrm{P}=0.084026$ & $\mathrm{P}=0.408574$ \\
\hline
\end{tabular}

\section{Discussion}

In the first half of $20^{\text {th }}$ century, renal calculi were treated with open surgery. The transition from open surgery to endoscopic surgery was facilitated by Rupel and Brown in 1941 by performing nephroscopy using a rigid cystoscope [9]. The technical aspects (puncture, tract dilatation, extraction, etc.) of percutaneous nephrolithotomy (PCNL) under fluoroscopy guidance were described by Fernström and Johansson in 1976 [10]. Further refinements in the technique of PCNL which we now preform today, were done by Dr. Arthur Smith, Dr. Kurt Amplatz, Dr. Peter Alken, all of whom helped establish PCNL as an effective alternative to open renal stone surgery with success rate more than 90\% [11]. Extracorporeal shock wave lithotripsy and retrograde intra-renal surgery are other non-invasive and minimally invasive options for management of renal calculi, however PCNL is the treatment of choice for stones $>20 \mathrm{~mm}$ [12].

Irrigating fluid is part and parcel of any endourological procedure. Due to its potential for absorption, it is also a sole or a partial contributory factor to hemodynamic and electrolyte complications arising from endourological procedures including PCNL. Amount of irrigation fluid absorption can be calculated by methods like breath ethanol test, serum acid phosphatase, plasma fluorescin, etc. [13] [14] [15]. TURP syndrome is the clinical manifestation occurring as the result of irrigation fluid absorption and can be seen in any endourological surgery with any irrigation fluid. Although uncommon, it may produce significant complications like dyspnea, cerebral edema, renal failure, cardiogenic shock [16].

The risk factors which play a role in complications of PCNL (TURP syndrome) are total operating time, total volume of irrigation fluid, irrigation fluid pressure, irrigation height, use of Amplatz sheath, perforation of renal pelvis or ureter. Fluid absorption can occur from retroperitoneal space due to rupture of 
renal pelvis or ureter, from peritoneal cavity, from veins of renal cortex during tract dilatation or veins in pelvi-calyceal system during stone fragmentation [17]. The extravasated fluid has been shown to increase the rate of complications as well as the duration of hospital stay [2]. The bacteria inside calculi get dislodged during fragmentation and can then migrate to intravascular compartment from extravasated fluid and lead to sepsis which is the most common cause of mortality arising from PCNL [18].

To reduce complications arising from absorption of irrigation fluid, multiple methods are used. They are reduction in total operating time and volume of irrigation fluid, staging of PCNL in case of pelvis perforation or bleeding hampering vision or high stone burden [19].

Immediately following PCNL, fall in hemoglobin, PCV and platelets is expected to be due to absorption of irrigation fluid or due to intravenous fluid injection and not due to acute blood loss. There is a process of hemodilution occurring due to fluid absorption. Saxena et al. found significant drop in hemoglobin, packed cell volume and platelets [6]. In their study of 40 patients. They concluded that the fall in hemoglobin was attributed to absorption of irrigation fluid as there was no correlation between IV fluids and changes in blood cell indices. They also found significant fall in sodium level. In our study, there was no significant drop in hemoglobin, PCV or platelets immediate post-operatively. Total operating time, irrigation volume, intravenous volume, BMI and ASA also did not correlate with the insignificant drop in hemoglobin, PCV and platelets. There was also no significant change in serum sodium level and was similar to study conducted by $\mathrm{Xu}, \mathrm{S}$ [3].

An immediate post-operative significant drop in serum creatinine $(1.30 \pm 0.96$ $\mathrm{mg} / \mathrm{dl}$ vs. $1.24 \pm 0.93 \mathrm{mg} / \mathrm{dl})$ and a rise in eGFR $(85.39 \pm 0.96 \mathrm{ml} / \mathrm{min}$ vs. $90.18 \pm$ $22.58 \mathrm{ml} / \mathrm{min}$ ) was present. Rise in eGFR correlated directly with total operating time and irrigation fluid volume and might also be the possible reason for the fall in creatinine. Mohta M. and Koroglu A. et al. showed no significant change in creatinine at end of 24 hours and end of irrigation, respectively. Mukherjee et al. showed a significant alteration in renal function at the end of 3 days as there was a significant rise in creatinine and fall in creatinine clearance and GFR [8]. These studies show that early changes in renal function tests are probably due to increased absorption of irrigation fluid leading to increased glomerular filtration. Long term alterations have been studied using DMSA SPECT and show a significant drop in renal function in the region of percutaneous access tract and the corresponding renal pole [20].

Moorthy HK showed significant rise of potassium when distilled water or 1.5\% glycine was used as irrigation fluid but no change in serum potassium when 0.95 normal saline was used. This was also seen in the study of 71 PCNL and MPCNL conducted by $\mathrm{Xu}, \mathrm{S}$ [3]. Mukherjee et al. showed that electrolytes remain normal 72 hours after PCNL [8]. In our study, as compared to pre-operative serum potassium values, we found a significant increase in immediate post-operative serum potassium level ( $4.34 \pm 2.2$ vs. $4.5 \pm 3.7)$. The rise in serum potassium correlated 
positively with amount of intravenous fluid injection. Ringer's lactate and plasmalyte are the fluids of choice in surgical patients, patients with trauma, burns and diabetic ketoacidosis as they are similar to extracellular fluid and cause faster improvement in acid-base changes [21]. However, as they contain a small amount of potassium, they can lead to a rise in serum potassium levels and can cause hyperkalemia. Hyperkalemia can lead to life threatening flaccid paralysis, cardiotoxicity and arrest of respiration if levels increase more than $7 \mathrm{mEq} / \mathrm{L}$ and can be diagnosed on ECG changes which may show tall $Q$ waves, flattening of $P$ wave, prolongation of QRS and PR intervals.

A significant rise in serum chloride was noted in our study $(104.79 \pm 3.51$ vs. $106.69 \pm 3.14$ ) and correlated with total operating time and irrigation fluid. Concentration of chloride is 1.5 times higher in $0.9 \%$ NS as compared to plasma. The excess chloride inhibits renin and aldosterone release and causes metabolic hyperchloremic acidosis [22]. In majority of healthy individuals with preserved renal function, this is usually a transient phenomenon. However, metabolic acidosis has been implicated in suppression of immune function and coagulopathy leading to increased post-operative complications like fever, hemorrhage, etc. and longer hospital stay [23].

Koroglu A, et al. showed no significant hemodynamic and electrolyte changes occurring in PCNL when 0.9\% NS was used for irrigation [18] while Atici S, et al., showed significant rise in systolic and diastolic blood pressure and fall in sodium, potassium and bicarbonate levels [7].

Pulse rate and blood pressure changes have been shown to be variable. No significant change was seen in study by Xu. S., Mohta M., et al. and Koroglu A., et al. [3] [4] [5] while Saxena et al. and Atici S., et al. [6] [7] showed a significant rise in post-operative pulse and blood pressure. They attributed the rise due to the effect of sympathetic stimulation during extubation and to the overactivity of renin-angiotensin pathway. In our study, significant rise in post-operative pulse rate and systolic blood pressure. The total irrigation volume showed positive correlation the rise of hemodynamic parameters. The intravenous fluids also showed correlation with rise in post-operative pulse rate and blood pressure. The expansion of intravascular fluid compartment is easily managed postoperatively with increase in urine output in healthy patients. However, this fluid overload can become significant in patients with chronic kidney disease and congestive heart failure thus showing the importance of cautious usage of irrigation and intravenous fluid during surgery.

Although acid-base balance changes were not measured in our study, metabolic acidosis has been found to occur in study by Mohta M, et al. [5]. They also suggested arterial blood gas examination perioperatively during PCNL especially in patients with chronic kidney disease and prolonged surgery.

The irrigation fluid of choice in patients suffering from chronic kidney disease is debatable. A study by Purkait B. in 76 patients with CKD were treated with PCNL and were divided into two groups in whom distilled water and $0.9 \%$ normal saline was used as irrigation fluid. They showed significant hyponatremia, 
hypokalemia and reduction in packed cell volume in distilled water group and recommended use of normal saline for irrigation in CKD patients due to better safety profile [24]. In our study including 6 patients with CKD, sodium and potassium levels did not change significantly but there was significant hyperchloremia. However, due to very low number of CKD patients in our study, we are unable to confidently conclude effects of irrigation fluid absorption and propose further randomized studies similar to Purkait B. Whenever indicated in patients without renal failure, distilled water can be used over normal saline as it has been shown to be equally safe in performing PCNL [25].

One of the limitations of our study was we did not measure the amount of irrigation fluid absorption by breath ethanol test. We also did not perform blood gas analysis and acid-base balance estimation.

\section{Conclusion}

A myriad of hemodynamic, hematological and serum electrolyte changes can occur because of irrigation fluid absorption and intravenous fluid injection during PCNL. Majority of these changes like hemodilution, hyponatremia, hyperchloremia, post-operative hypertension, etc. are transient and recover with time. However, changes can occur (hyperkalemia, metabolic acidosis) which can lead to increased post-operative morbidity and hospital stay and which need to be corrected immediately. Thus, we recommend early post-operative monitoring of serum electrolytes to be done in all patients after PCNL to prevent complications arising from dyselectrolytemia.

\section{Conflicts of Interest}

The authors declare no conflicts of interest regarding the publication of this paper.

\section{References}

[1] Lang, E.K. (1987) Percutaneous Nephrostolithotomy and Lithotripsy: A MultiInstitutional Survey of Complications. Radiology, 162, 25-30. https://doi.org/10.1148/radiology.162.1.3786771

[2] Gehring, H., Nahm, W., Zimmermann, K., Fornara, P., Ocklitz, E. and Schmucker, P. (1999) Irrigating Fluid Absorption during Percutaneous Nephrolithotripsy. Acta Anaesthesiol Scand, 43, 316-321. https://doi.org/10.1034/j.1399-6576.1999.430312.x

[3] Xu, S., Shi, H., Zhu, J., et al. (2014) A Prospective Comparative Study of Haemodynamic, Electrolyte, and Metabolic Changes during Percutaneous Nephrolithotomy and Minimally Invasive Percutaneous Nephrolithotomy. World Journal of Urology, 32, 1275-1280. https://doi.org/10.1007/s00345-013-1204-2

[4] Atici, S., Zeren, S. and Aribogan, A. (2001) Hormonal and Hemodynamic Changes during Percutaneous Nephrolithotomy. International Urology and Nephrology, 32, 311-314. https://doi.org/10.1023/A:1017527126481

[5] Mohta, M., Bhagchandani, T., Tyagi, A., et al. (2008) Haemodynamic, Electrolyte and Metabolic Changes during Percutaneous Nephrolithotomy. International Urology and Nephrology, 40, 477-482. https://doi.org/10.1007/s11255-006-9093-6 
[6] Dipti, S., Divyangna, S., Atul, D., Saurabh, C. and Santosh, A. (2019) Effects of Fluid Absorption following Percutaneous Nephrolithotomy: Changes in Blood Cell Indices and Electrolytes. Urology Annals, 11, 163-167. https://doi.org/10.4103/UA.UA_117_18

[7] Atici, S., Zeren, S. and Aribogan, A. (2001) Hormonal and Hemodynamic Changes during Percutaneous Nephrolithotomy. International Urology and Nephrology, 32, 311-314. https://doi.org/10.1023/A:1017527126481

[8] Mukherjee, S., Sinha, R.K., Jindal, T., et al. (2019) Short-Term Alteration of Renal Function and Electrolytes after Percutaneous Nephrolithotomy. Urology Journal, 16, 530-535.

[9] Rupel, E. and Brown, R. (1941) Nephroscopy with Removal of Stone Following Nephrostomy for Obstructive Calculus Anuria. Journal of Urology, 46, 177-182. https://doi.org/10.1016/S0022-5347(17)70906-8

[10] Fernstrom, I. and Johannsson, B. (1976) Percutaneous Pyelolithotomy. A New Extraction Technique. Scandinavian Journal of Urology and Nephrology, 10, 257-259. https://doi.org/10.1080/21681805.1976.11882084

[11] Castaneda-Zuniga, W.R., Clayman, R., Smith, A., Rusnak, B., Herrera, M. and Amplatz, K. (2002) Nephrostolithotomy: Percutaneous Techniques for Urinary Calculus Removal. Journal of Urology, 167, 849-853. https://doi.org/10.1016/S0022-5347(02)80276-2

[12] Dean Assimos, M.D., Amy Krambeck, M.D., Nicole, L., Miller, M.D., et al. (2016) Surgical Management of Stones: AUA/Endourology Society Guideline.

[13] Oku, S., Kadowaki, T., Uemura, T. and Nishioka, H. (1993) Early Detection of Absorption of Irrigating Fluid during Transurethral Resection of the Prostate with Alcohol Gas Detector Tube. Nippon Hinyokika Gakkai Zasshi, 84, 374-381. https://doi.org/10.5980/jpnjurol1989.84.374

[14] Hahn, R.G. (1989) Acid Phosphatase Levels in Serum during Transurethral Prostatectomy. British Journal of Urology, 64, 500-503. https://doi.org/10.1111/j.1464-410X.1989.tb05286.x

[15] Bender, D.A. and Coppinger, S.W. (1992) Estimation of Irrigant Absorption during Transurethral Resection of the Prostate-Assessment of Fluorescein as a Marker. Urological Research, 20, 67-69. https://doi.org/10.1007/BF00294340

[16] Tausin, F.P. and Sans, L. (1992) Prostate Transurethral Resection Syndrome. Annales Francaises D'anesthesie et de Reanimation, 11, 168-169.

[17] Rao, P.N. (1987) Fluid Absorption during Urological Endoscopy. British Journal of Urology, 60, 93-99. https://doi.org/10.1111/j.1464-410X.1987.tb04940.x

[18] O’Keeffe, N.K., Mortimer, A.J., Sambrook, P.A. and Rao, P.N. (1993) Severe Sepsis Following Percutaneous or Endoscopic Procedures for Urinary Tract Stones. British Journal of Urology, 72, 277-283. https://doi.org/10.1111/j.1464-410X.1993.tb00717.x

[19] Kukreja, R.A., Desai, M.R., Sabnis, R.B. and Patel, S.H. (2002) Fluid Absorption During Percutaneous Nephrolithotomy: Does It Matter? Journal of Endourology, 16, 221-224. https://doi.org/10.1089/089277902753752160

[20] Aguiar, P., Pérez-Fentes, D., Garrido, M., García, C., Ruibal, Á. and Cortés, J. (2016) A Method for Estimating DMSA SPECT Renal Function for Assessing the Effect of Percutaneous Nephrolithotripsy on the Treated Pole. The Quarterly Journal of Nuclear Medicine and Molecular Imaging, 60, 154-162.

[21] Chua, H.R., Venkatesh, B., Stachowski, E., et al. (2012) Plasma-Lyte 148 vs $0.9 \%$ Sa- 
line for Fluid Resuscitation in Diabetic Ketoacidosis. Journal of Critical Care, 27, 138-145. https://doi.org/10.1016/j.jcrc.2012.01.007

[22] El Gkotmi, N., Kosmeri, C., Filippatos, T.D. and Elisaf, M.S. (2017) Use of Intravenous Fluids/Solutions: A Narrative Review. Current Medical Research and Opinion, 33, 459-471. https://doi.org/10.1080/03007995.2016.1261819

[23] McCluskey, S.A., Karkouti, K., Wijeysundera, D., et al. (2013) Hyperchloremia after Noncardiac Surgery is Independently Associated with Increased Morbidity and Mortality: A Propensity-Matched Cohort Study. Anesthesia \& Analgesia, 117, 412-421. https://doi.org/10.1213/ANE.0b013e318293d81e

[24] Purkait, B., Kumar, M., Bansal, A., Sokhal, A.K., Sankhwar, S.N. and Singh, K. (2016) Is Normal Saline the Best Irrigation Fluid to Be Used during Percutaneous Nephrolithotomy in Renal Failure Patient? A Prospective Randomized Controlled trial. Turkish Journal of Urology, 42, 267-271.

https://doi.org/10.5152/tud.2016.46690

[25] Aghamir, S.M.K., Alizadeh, F., Meysamie, A., Assefi Rad, S. and Edrisi, L. (2009) Sterile Water Versus Isotonic Saline Solution as Irrigation Fluid in Percutaneous Nephrolithotomy. Urology Journal, 6, 249-253. 